\title{
A Computer-Based System for Evaluation of Slub Yarn Characteristics
}

\author{
R. Abd El-khalek, R. El-Bealy, and A. El-Deeb \\ Textile Engineering Department, Faculty of Engineering, Mansoura University, Mansoura 35516, Egypt \\ Correspondence should be addressed to R. Abd El-khalek; rehab_ali1976@yahoo.com
}

Received 24 August 2013; Revised 7 November 2013; Accepted 26 November 2013; Published 9 January 2014

Academic Editor: Anindya Ghosh

Copyright (C) 2014 R. Abd El-khalek et al. This is an open access article distributed under the Creative Commons Attribution License, which permits unrestricted use, distribution, and reproduction in any medium, provided the original work is properly cited.

\begin{abstract}
This research aims to build a computer-based system for measuring slub yarn characteristics and evaluating the results using statistical methods. The measuring system was based on the electrical condenser of the Uster evenness tester as a measuring sensor. A digital storage oscilloscope was used to convert the analogue output signals into digital data to be recorded on a computer. A designed computer program was constructed using MatLab language for signal analysis based on a proposed method. Final results from this system contained graphical plots for the three measured slub yarn geometrical parameters slub length, slub distance, and slub thickness and a final report for all the measured slub yarn characteristics. The results of tested slub yarn samples showed that actual slub geometrical parameters differ from nominal values and the difference had two level: prevailing difference and outlier values. Outliers which are considered slub yarn defects were detected and counted in a final report using the box plot statistical method which could be an effective industrial tool for evaluation of both yarn quality and machine performance. The prevailing difference was assessed using histogram comparison which could help in adjusting the setting of slub yarn device to obtain the required appearance.
\end{abstract}

\section{Introduction}

Ground slub yarn is a simple fancy yarn whose slub appearance is gained by the variation of yarn linear density during spinning process and no additional yarn or process is required. It is used to produce an acceptable handle and fancy appearance mainly for plain conventional fabrics. Slub yarns could be produced by modifying ring spinning frame, such that the intermittent acceleration of the rollers will cause varying degrees of draft to be applied [1]. The programmed electronic control of two or more separate variable speed motors for each drafting roller enabled leading companies to produce such new drafting systems to obtain a wide range of slub yarn characteristics.

Evaluation of slub yarn characteristics which are different from conventional yarn is very important in the slub yarn manufacturing process as they determine the final appearance of the produced fabric. The traditional manual measuring method based on the black board and using standard measuring scales is time consuming. Different methods for measuring slub geometrical parameters, that is, slub length, slub distance, and slub thickness, were introduced in recent researches. Sudhakar [2] used and compared between different methods for measuring slub geometrical parameters. Slub length and slub thickness were measured using image analysis methods from slub yarn images captured using a flat scanner. Slub thickness was also measured using a yarn profile tester which is an imaging system that uses a charged coupled device (CCD) array to collect the yarn profile as the yarn moves through the imaging system. Slub length and slub distance were measured using the same imaging system of the yarn profiler tester and another software (Electronic inspection Board CTT EIB software). Pan et al. [3] used image analysis methods to measure slub length, slub distance, and slub thickness from slub yarn images captured using a flat scanner and used ID Fourier transform to identify the period of slubs for periodic slub yarns. Image analysis method is limited by size of captured image and parameters 


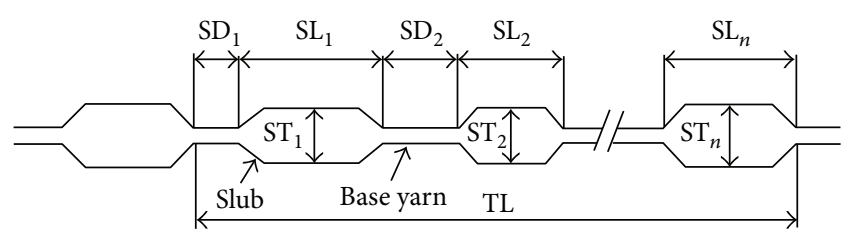

FIGURE 1: Slub yarn geometrical parameters.

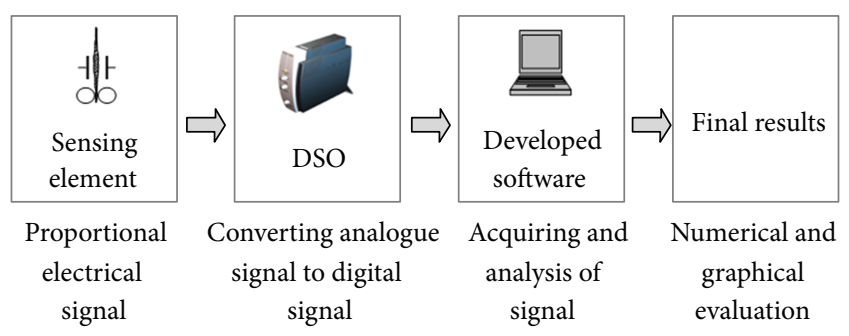

FIGURE 2: Block diagram for the measuring system.

that have length higher than the maximum image size of image capturing equipment cannot be measured. Thus, slub distance could not be measured by Sudhakar [2] or only slub yarn samples with short slub distance were used by Pan et al. [3]. Using image analysis method for measuring slub diameter which could be affected by the filling ratio and twist amount may not accurately represent slub thickness which is a relative mass change. Liu et al. [4] introduced an analytical method of determining two slub parameters: slub length and distance from voltage signals acquired from a capacitance type sensor. The method depends on eliminating the noise signal by low pass filtration, separating the slub part signal to build a pulse signal using the dynamic threshold, and confirming the parameters by observing the $2 \mathrm{D}$ image and pulse signal. Liu and $\mathrm{Lu}$ [5] introduced a method for recognition of the three slub yarn parameters based on FFT (fast Fourier transform) to filter the voltage signals from a capacitive-type sensor. Liu et al. [6] introduced a clustering analysis method for characterizing the two slub parameters: slub length and distance. Uster technologies AG introduced the slub yarn evaluation tool "Fancy yarn Profile" which is a software option to the Uster tester 5 [7] and pointed out that the appearance of the resulting slub does not necessary coincide with the setting at slub yarn device of the spinning machine, that is, nominal values which was also reported by Liu et al. [4-6].

This research aims to build a computer-based system using the electrical condenser of the Uster evenness tester as a sensor for measuring slub yarn characteristics and evaluating the results using statistical methods in order to detect and assess the difference between actual and nominal values.

\section{Slub Yarn Characteristics}

A ground slub yarn is formed of a single structure that has two parts: slub part and base yarn part. The basic geometrical parameters of slub yarn as shown in Figure 1 are slub length (SL), slub distance (SD) which represents the length of base yarn between two successive slubs, and slub thickness (ST) which represents the mass ratio between slub part and base yarn.

Other parameters that characterize a slub yarn produced with a repeat pattern containing $n$ number of slubs could be calculated according to the following equations:

$$
\text { Total slub length }=\sum_{i=1}^{n} \mathrm{SL} i=\mathrm{SL}_{1}+\mathrm{SL}_{2}+\cdots \mathrm{SL}_{n}
$$

Total slub distance length

$$
=\sum_{i=1}^{n} \mathrm{SD} i=\mathrm{SD}_{1}+\mathrm{SD}_{2}+\cdots \mathrm{SD}_{n}
$$

Total pattern length $(\mathrm{TL})=\sum_{i=1}^{n} \mathrm{~S} L i+\sum_{i=1}^{n} \mathrm{SD} i$,

Slub per meter $(S / m)=\frac{n}{T L}$,

Sub length percentage (SL\%) $=\frac{\sum_{i=1}^{n} \mathrm{SL} i}{\sum_{i=1}^{n} \mathrm{SL} i+\sum_{i=1}^{n} \mathrm{SD} i} \cdot 100$,

Slub distances percentage (SD\%)

$$
\begin{gathered}
=\frac{\sum_{i=1}^{n} \mathrm{SD} i}{\sum_{i=1}^{n} \mathrm{SD} i+\sum_{i=1}^{n} \mathrm{SL} i} * 100, \\
\text { Mean of slub length (SLm) }=\frac{\sum_{i=1}^{n} \mathrm{SL} i}{n}, \\
\text { Mean of slub distance (SDm) }=\frac{\sum_{i=1}^{n} \mathrm{SD} i}{n}, \\
\text { Mean of slub thickness (STm) }=\frac{\sum_{i=1}^{n} \mathrm{ST}}{n} .
\end{gathered}
$$

\section{Measuring System}

Figure 2 shows a block diagram for the measuring system where the electric condenser of the USTER Evenness Tester I was used as the measuring sensor. The electric output signal was fed into a digital storage oscilloscope DSO (Velleman PcSU1000) to convert the analogue signal to digital data in order to be recorded on a computer using the installed software of the DSO and then analyzed by using a constructed software program.

3.1. Signal Recording. In order to obtain an accurate indication of the base yarn mean value, the measuring slot number was chosen according to the base yarn count. According to the application handbook for evenness testers by Uster [8], variation of more than $500 \%$ in the cross-section from the yarn mean value could be detected.

To process the analog signal in computers, it must be converted to "digital" form. While an analogue signal is continuous in both time and amplitude, a digital signal is discrete in both time and amplitude. To convert a signal from 


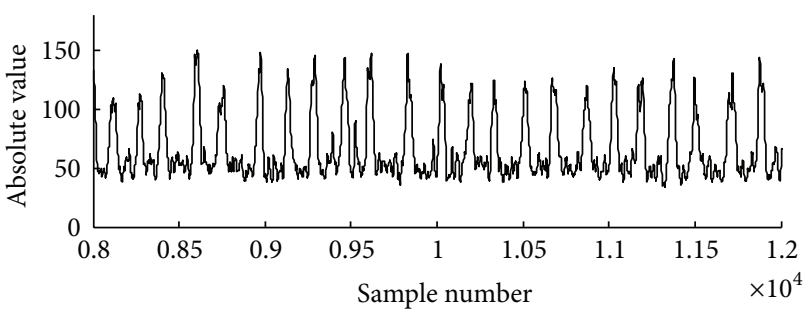

Figure 3: A part of a recorded signal for a slub yarn sample.

continues time to discrete time, a process called sampling is used. The value of the signal is measured at certain intervals in time. Each measurement is referred to as a sample. The sampling is done using a sampling rate or sampling frequency which is defined as the number of samples obtained in one second (samples per second). To keep the data organized, each sample is assigned a sample number or index. These are the numbers that appear along the horizontal axis of the digitized signal [9]. The number of samples recorded per unit length depends on both testing speed (length per unit time) and sample frequency (no. of samples per unit time). At higher speed and low sample frequency if the number of slubs per unit length increases this may results in losing of some slubs or recording low number of samples for each slub. In this study, signals were recorded at sample frequency of 100 sample/sec which is a specification of the DSO; thus, a speed of $8 \mathrm{~m} / \mathrm{min}$ was convenient to ensure that every slub is represented by a quite sufficient number of samples.

Signal recording included two steps. Firstly, recording a signal for the tested slub yarn sample and secondly, recording the output value of measuring circuit when the base yarn is found between the measuring electrodes without drawing it through the measuring slot. Ten different values were recorded for ten different points along the base yarn. The aim of this step is to estimate an initial approximated value of base yarn mean.

3.2. Signal Analysis. Figure 3 shows a part of a recorded signal for a slub yarn sample in which the sample number on $x$-axis could be converted to its original value as time using the sample frequency and the absolute display value of the oscilloscope on the $y$-axis could be converted to its original value as volt using the voltage step $(32=1$ volt $)$. A computer program was constructed using MatLab language (version 7.01) for signal analysis and evaluation of slub yarn characteristic. Figure 4 shows the main stages in the proposed signal analysis method.

After acquiring the digital data of signals the $x$-axis and $y$ axis were represented as distance and mass ratio, respectively, as follows.

(i) Separation of the base yarn signal from slub yarn signal: the aim of this step is to determine an accurate mean value of the base yarn. This process is done by thresholding slub yarn signal using the initial approximated value of base yarn mean as a threshold value. Figure 5 shows the separated base yarn signal from the part of recorded signal in Figure 3.

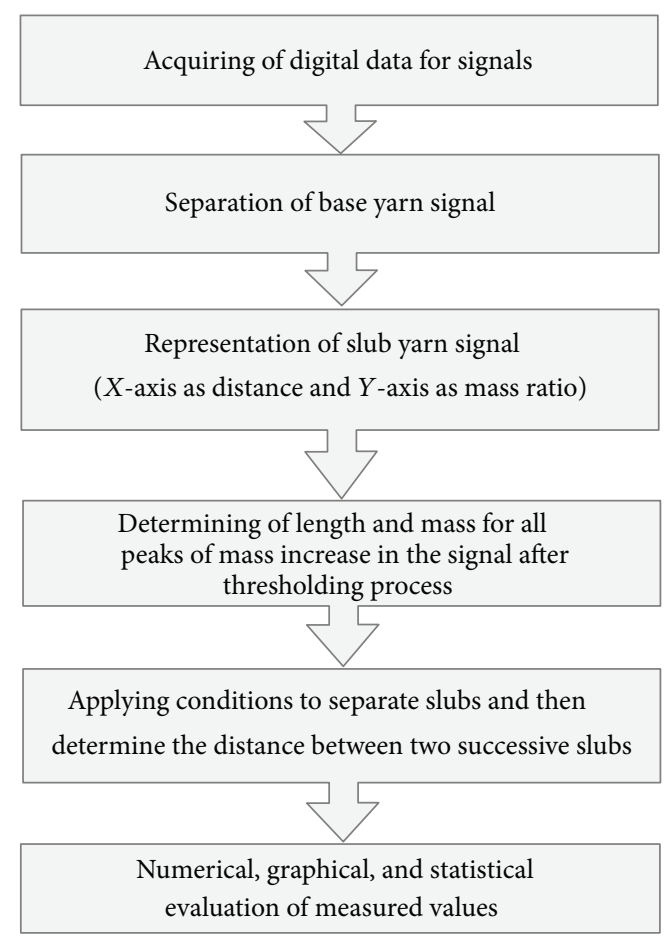

FIGURE 4: Main stages in the proposed method of signal analysis.

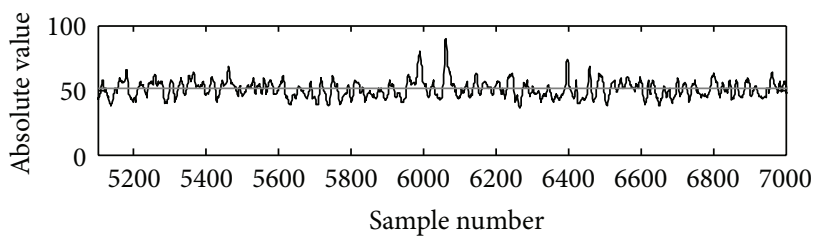

FIGURE 5: A part of separated base yarn signal from the recorded slub yarn signal in Figure 3.

(ii) The $y$-axis was converted from volt to mass ratio by dividing every sample value in the slub yarn signal by the determined base yarn mean value.

(iii) The $x$-axis was converted from time to length using a conversion constant $(\mathrm{cm} / \mathrm{sample})$ which is determined using test speed and sample frequency.

Figure 6 shows a zoomed part of a slub yarn signal after representing $x$ and $y$-axis. Slub length was measured between the starts point of the slub where the yarn thickness start to increase and the end point of the slub where the yarn thickness reaches its original thickness. Slub distance was measured between the start of the slub to the end of the previous slub. As normal mass variation along slub length appears along the flat part of slub length therefore slub relative thickness was measured as the distance between the average peak value, that is, [maximum peak $(\mathrm{A})+$ minimum trough (B)]/2 and the base yarn line. Slubs were then identified after thresholding and using of separation conditions to differentiate between slubs and other peaks of normal mass increase in the base yarn. The threshold value $(1.15 *$ base yarn mean value) was chosen based on the comparison between 


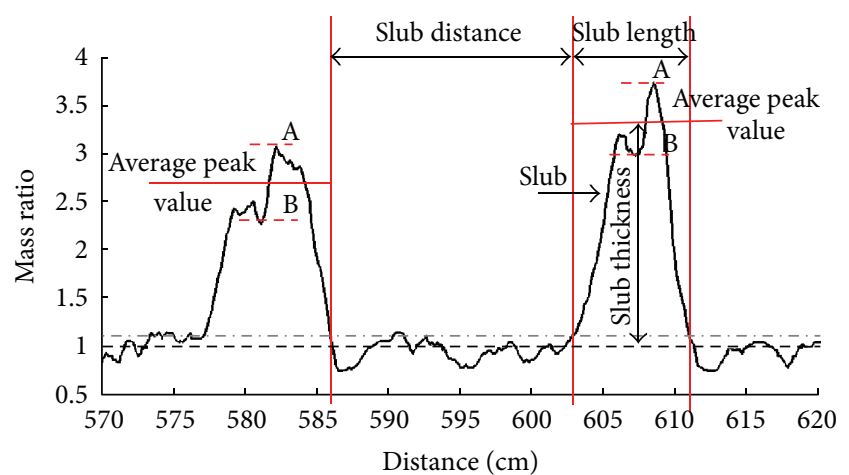

$$
\begin{array}{ll}
\text { _- Slub yarn } \\
\text { - - } & \text { Base yarn } \\
\text {-.- } & \text { Threshold line }
\end{array}
$$

FIGURE 6: Feature extractions of slub yarn geometrical parameters from the recorded signal.

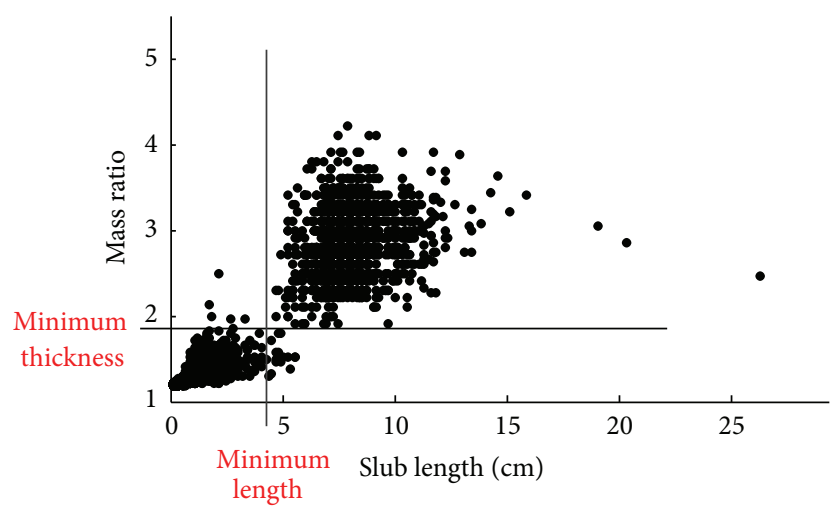

FIGURE 7: Identifying slubs after measuring the length and mass ratio for every peak exceeds the threshold value.

results from traditional measuring method and the proposed analysis method to obtain a high correlation. The length and thickness were measured for every peak that exceeds the threshold value. Exceeding the minimum limits of slub length and slub thickness is the separation condition as shown in Figure 7. After identifying slubs, distances between every two successive slubs were measured.

3.3. Reliability of the Measuring Method. A signal for a short sample of slub yarn marked by two knots at its both ends was recorded as shown in Figure 8. Slub lengths and distances between knots were measured using the conventional measuring with a ruler under magnifier and then compared with results from the previous proposed method for the same part of yarn. As shown from Figure 9, there is a very high correspondence between measurements from both methods.

By using the capacitor sensor the length of the shortest mass variations which can be recorded is mainly dependent on the length of the measuring field which is formed by the electrode plates. This length of measuring field results in the fact that the mean value of mass which lies between the measuring electrodes is determined and indicated. According to Uster-Manual of evenness testing variations which are

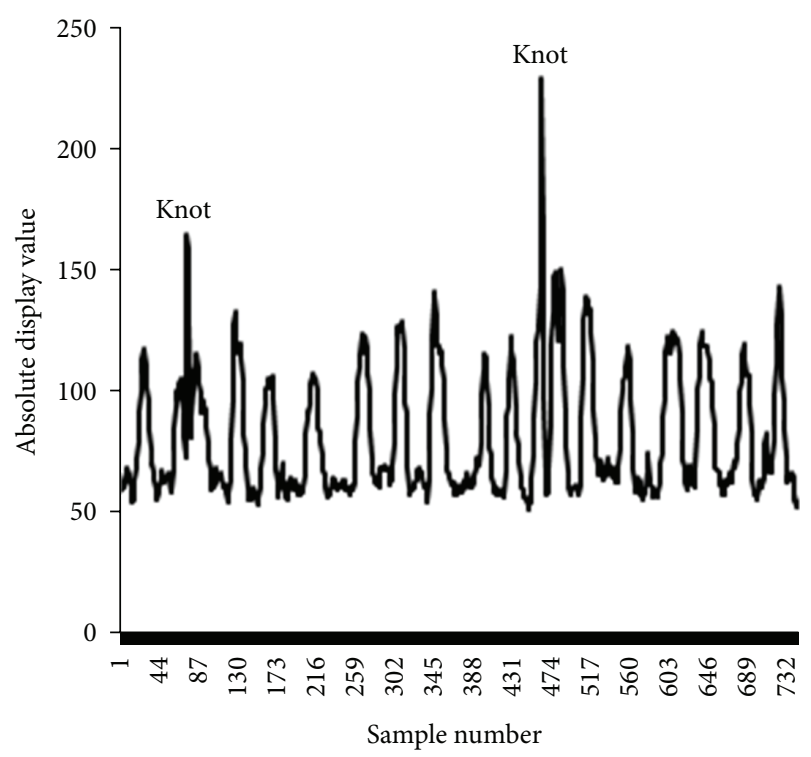

FIgURE 8: A recorded signal for a short length of slub yarn between two knots.

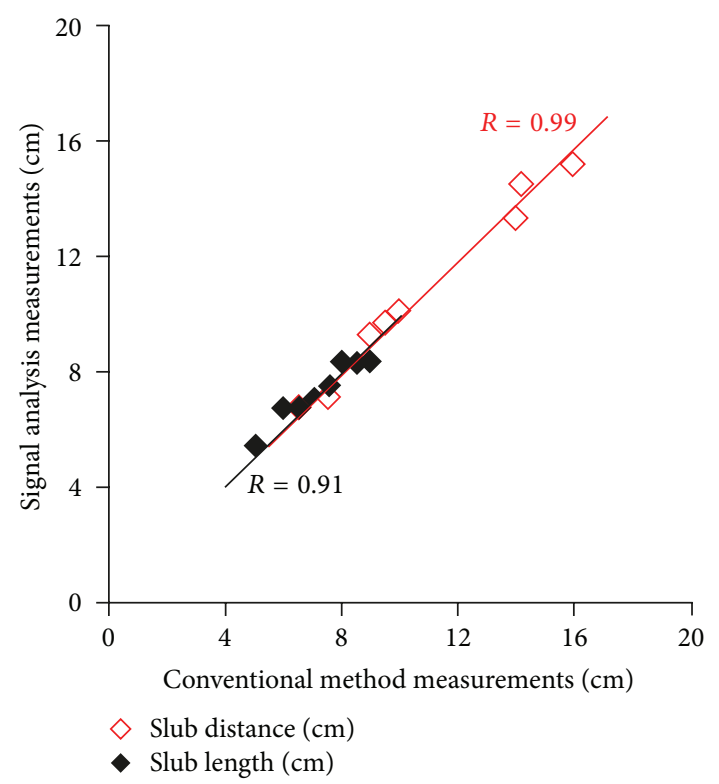

FIGURE 9: Measurements of signal analysis method plotted against measurements of conventional method.

shorter than the measuring field length cannot be indicated according to their full amount but appear as a reduced value according to a certain relationship. The resulting decrease of the indication at the $8 \mathrm{~mm}$ electrode (used in yarn testing) is negligibly small for fiber length larger than approximately $25 \mathrm{~mm}$ as prooved by Breny [10].

3.4. Statistical Evaluation of the Measured Slub Yarn Geometrical Parameters. In order to identify slub yarn samples with outlier characteristics box plot statistical method was used in which two levels of outliers could be identified [11]. If the measured value is at least 1.5 interquartile ranges (IQR) 


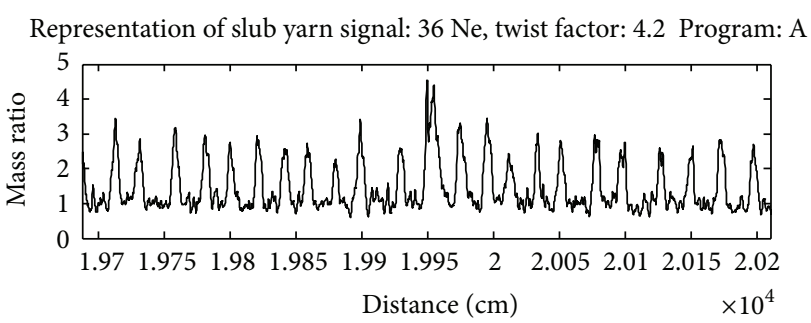

FIGURE 10: A part of the recorded signal for slub yarn sample number 1.

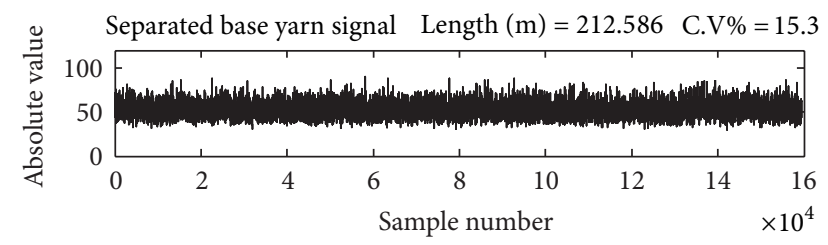

FIGURE 11: The separated base yarn signal for slub yarn sample number 1 .
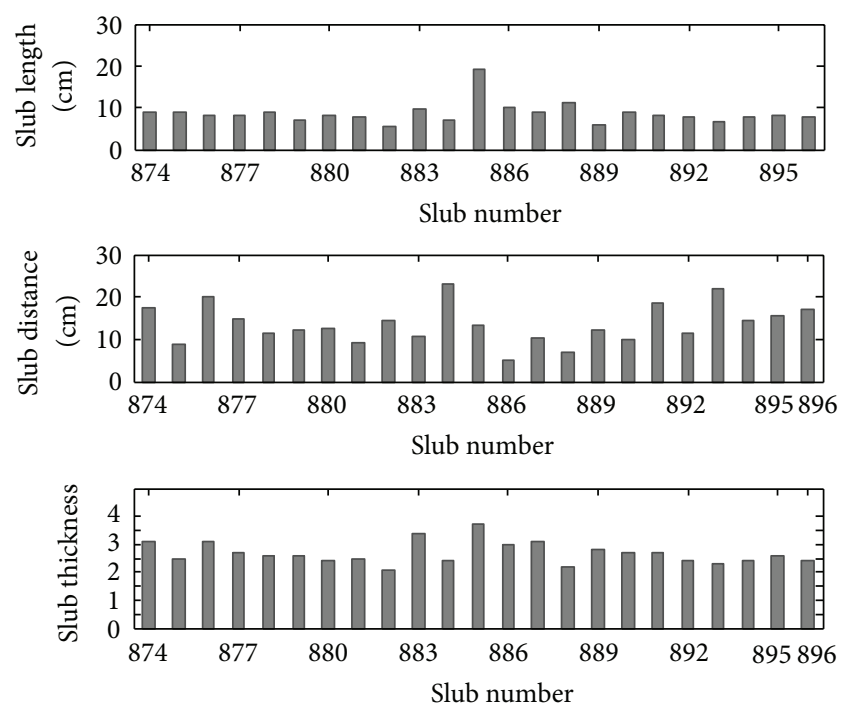

FIgURE 12: A part of the bar charts for the measured slub parameters for slub yarn sample number 1 .

below the first quartile or at least 1.5 interquartile ranges (IQR) above the third quartile it is detected as a close outlier value, for example, long or low slub length, long or low slub distance, and high or low slub thickness. If the value is at least 3 interquartile ranges (IQR) below the first quartile or at least 3 interquartile ranges (IQR) above the third quartile it is detected as a very far outlier or extreme for example, very long or very low slub length, very long or very low slub distance, very high or very low slub thickness. Therefore, a final report which includes 12 different items of outliers was obtained. In order to assess the deviation between the nominal and the actual values of slub geometrical parameters, the system is prepared to compare between the two datasets using histograms.
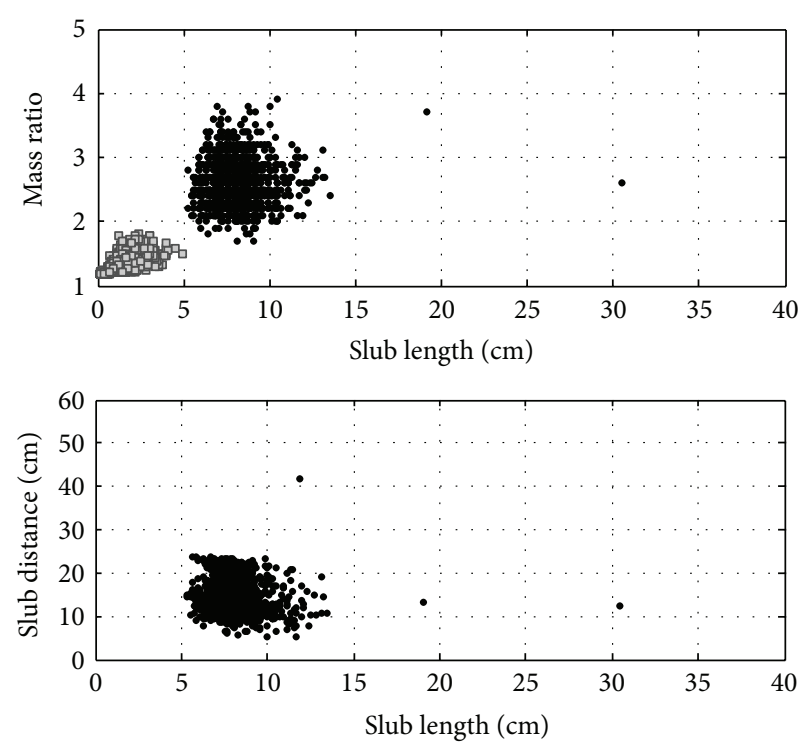

- Slubs

- Thick places in base yarn

FIGURE 13: Measured values of slub length against slub thickness and slub distance for sample number 1 .

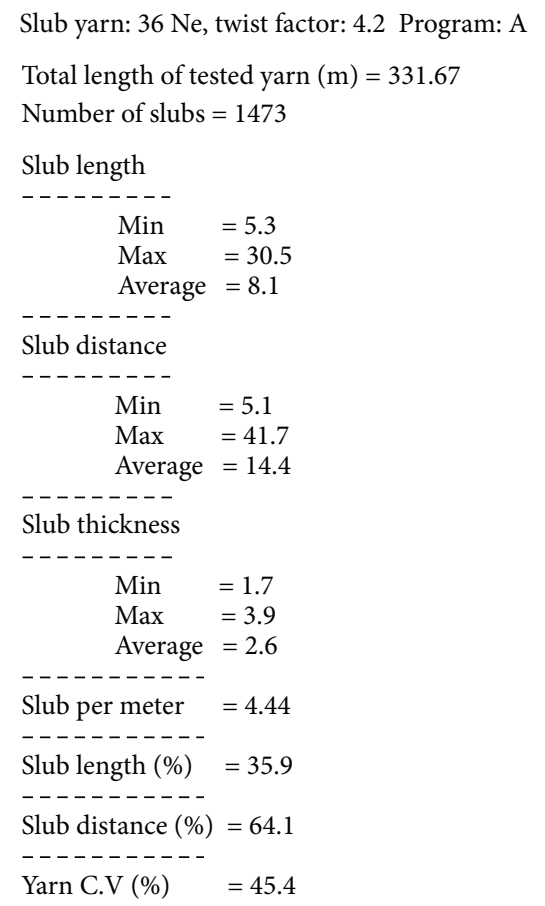

FIGURE 14: Final report for all the measured slub yarn characteristics in sample number 1 .

\section{Experimental Work}

In this study, slub yarn samples with different count and twist factor produced by CAIPO slub device [12] were tested. The different patterns of slub yarn were designed using a software program installed on a computer. Each pattern of slub yarn consists of a number of steps equal to the number of slubs 

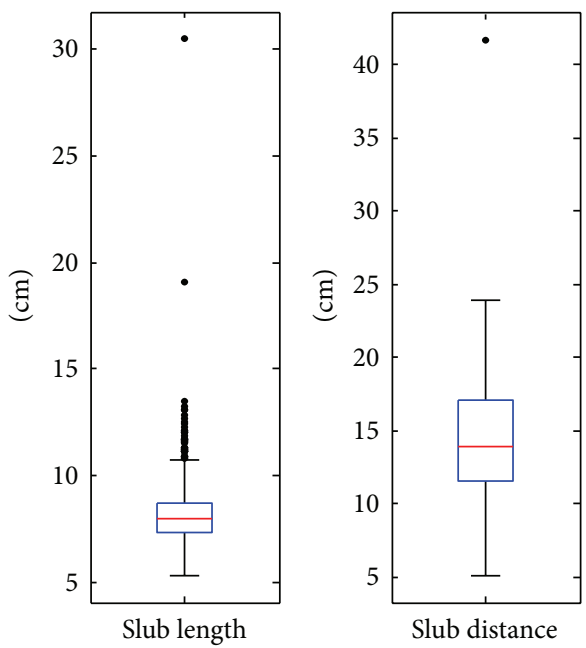

(a)

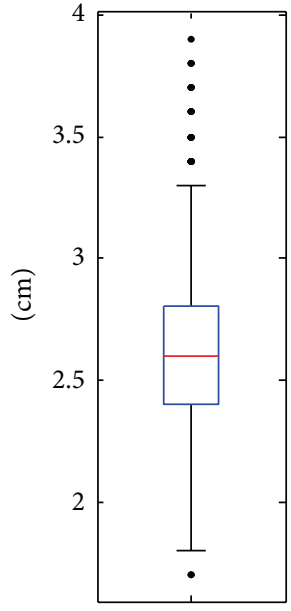

Slub thickness
Slub yarn: $36 \mathrm{Ne}$, twist factor: 4.2 Program: A

Total length of tested yarn $(\mathrm{m})=331.67$

Number of slubs $=1473$

Slub length:

$\begin{array}{lcll}\text { - Long } & 48 & \text { - Low } & 0 \\ \text { - Very long } & 6 & \text { - Very low } & 0\end{array}$

Slub distance:

- Long 1 - Low 0

- Very long 1 - Very low 0

Slub thickness

$\begin{array}{llll}\text { - High } & 35 & \text { - Low } & 2 \\ \text { - Very high } & 0 & \text { - Very low } & 0\end{array}$

(b)

Figure 15: (a) Box plots for measured slub geometrical parameters. (b) Report of the number of detected outliers in slub yarn sample number 1.

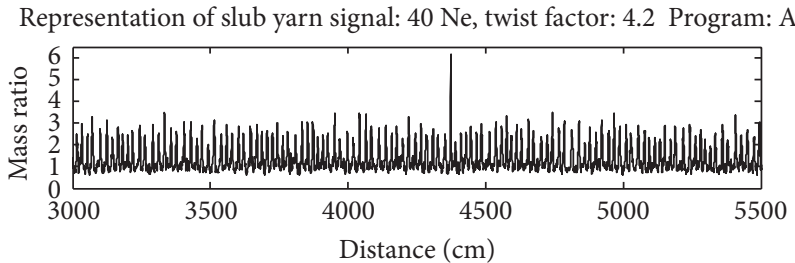

FIGURE 16: A part of the recorded signal for slub yarn sample number 2.

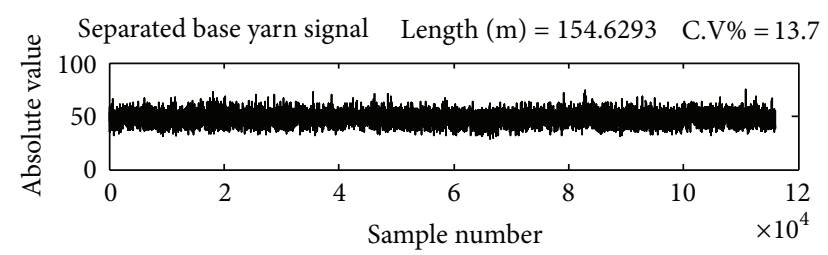

FIGURE 17: The separated base yarn signal for slub yarn sample number 2.

per repeat. Each step holds the following information: slub distance $(\mathrm{cm})$, slub length $(\mathrm{cm})$, and slub thickness. This information is created randomly between a minimum and a maximum value for each slub parameter. Table 1 shows setting of each slub yarn pattern and slub yarn characteristics which were calculated from the detailed information of each pattern using equations in Section 2.

\section{Results and Discussion}

Final results from the signal analysis program for different slub yarn samples were as follows.

Sample Number 1. Figure 10 shows a part of a recorded signal for slub yarn sample of $36 \mathrm{Ne}$ produced from carded Egyptian cotton with $4.2 \alpha$ e using slub yarn pattern A. Figure 11 shows the separated base yarn signal where the measured C.V of the
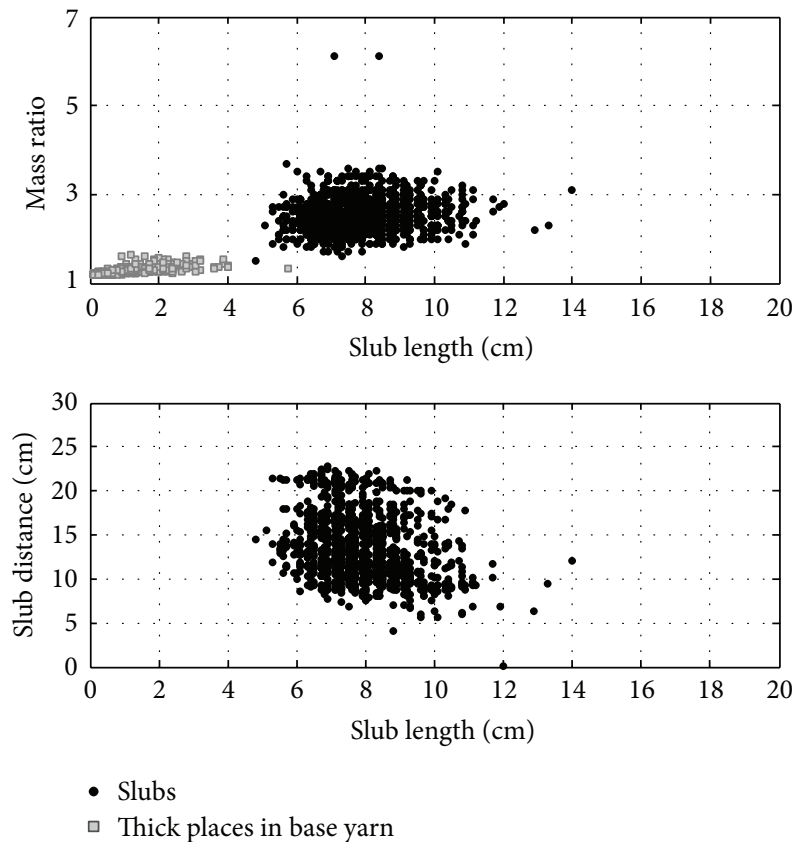

FIGURE 18: Measured values of slub length against slub thickness and slub distance for sample number 2 .

$212.59 \mathrm{~m}$ was $15.3 \%$. Figure 12 shows a part of the measured values of slub length, slub distance, and slub thickness for the 23 successive slubs shown in Figure 10. Figure 13 shows all the measured values of slub length plotted against slub thickness and slub distance. Figure 14 shows the final report of all the measured characteristics where the tested length was $331.67 \mathrm{~m}$ with 1473 slubs. Figure 15(a) shows box plots of the measured parameters: slub length, slub distance, and slub thickness and Figure 15(b) shows the final report of the number of detected outliers in which, for example, 6 slubs with extreme length (very long slub) and one slub with extreme slub distance (very long slub distance) were detected. 


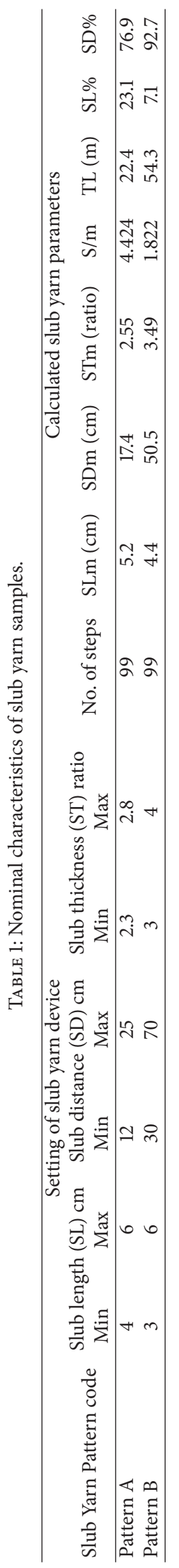


TABLE 2: Difference between actual and nominal values.

\begin{tabular}{|c|c|c|c|c|c|}
\hline \multicolumn{2}{|c|}{ Tested samples } & \multicolumn{4}{|c|}{ Actual value - nominal value } \\
\hline & & SLm $(\mathrm{cm})$ & $\mathrm{SDm}(\mathrm{cm})$ & STm (ratio) & $\mathrm{TL}(\mathrm{m})$ \\
\hline No. 3 & $36 \mathrm{Ne}, 3.6 \alpha e$, pattern B & 3.2 & -4.8 & 0.18 & -0.6 \\
\hline No. 4 & $36 \mathrm{Ne}, 3.6 \alpha e$, pattern $\mathrm{A}$ & 2.6 & -3 & 0.22 & -0.5 \\
\hline No. 5 & $24 \mathrm{Ne}, 3.6 \alpha e$, pattern $\mathrm{A}$ & 2.2 & -2.8 & 0.25 & -0.6 \\
\hline
\end{tabular}

Slub yarn: $40 \mathrm{Ne}$, twist factor: 4.2 Program: A

$$
\begin{aligned}
\text { Number of slubs } & =1138 \\
\text { Slub length } & \\
\text { Min } & =4.8 \\
\text { Average } & =7.9 \\
------ & \\
\text { Slub distance } & \\
------- & \\
\text { Min } & =0.1 \\
\text { Maxerage } & =13.6 \\
------- & \\
\text { Slub thickness } & \\
-------- & \\
\text { Min } & =1.5 \\
\text { Max } & =6.1 \\
\text { Average } & =2.5 \\
- \text { Slub per meter } & =4.66 \\
---------- & \\
\text { Slub length }(\%) & =36.7 \\
---------- & \\
\text { Slub distance }(\%) & =63.3 \\
---------- & \\
\text { Yarn C.V }(\%) & =44.5
\end{aligned}
$$$$
\text { Total length of tested yarn }(\mathrm{m})=244.18
$$

FIGURE 19: Final report for all the measured slub yarn characteristics in sample number 2 .

Sample Number 2. Figure 16 shows a part of a recorded signal for a slub yarn sample of $40 \mathrm{Ne}$ produced from combed Egyptian cotton with $4.2 \alpha$ e using slub yarn pattern A. Figure 17 shows the separated base yarn signal where the measured C.V of the $154.63 \mathrm{~m}$ was $13.7 \%$. Figure 18 shows all the measured values of slub length plotted against slub thickness and slub distance. Figure 19 shows the final report of all the measured characteristics in a tested length of $244.18 \mathrm{~m}$ with 1138 slubs. As shown in Figures 20(a) and 20(b) two extreme values of slub thickness (very high) and one extreme value of slub length (very long) for example were detected.

Results in the previous two samples showed that the difference between actual and nominal slub yarn geometrical parameters had two levels: the first is the prevailing difference and the second is the outlier values. The detected outliers in the measured slub geometrical parameters are probably caused by electronic signal malfunctioning. Very far outliers (extremes) such as very long slubs as marked by the arrow in Figures 21(a) and 21(b) or very long slub distance as marked by the arrow in Figure 21(c) will have a more noticeable adverse effect on fabric appearance than close outlier values such as low distance as marked by the arrow in Figure 22(a) or long slub distance as marked by the arrow in Figure 22(b). The decrease in slub thickness to the extent that it is classified as a mass increase in the base yarn after applying the separation condition to identify slubs resulted in detecting long slub distance as shown in Figure 22(c).

As shown in the final reports of the measured slub yarn characteristics in Figures 14 and 19 for sample number 1 and 2, respectively, actual mean of slub length (SLm) increased more than the nominal value by a value of 2.9 and $2.7 \mathrm{~cm}$, actual mean of slub distance (SDm) decreased, than the nominal value by a value of 3 and $3.8 \mathrm{~cm}$, and actual mean of slub thickness varied by a slight value of +0.05 and -0.05 in samples numbers 1 and 2, respectively. In order to assess this prevailing difference histogram comparison for three different slub yarn samples (samples numbers 3, 4, and 5) with no extreme characteristics were obtained. Slub yarn characteristics were measured in three different recorded signals for each sample. Each recorded signal represents one pattern repeat (99 successive slubs) with no extreme characteristics. Figures 23 and 24 show results of one of the three recorded signals for slub yarn sample number 3 of $36 \mathrm{Ne}$ produced from carded Egyptian cotton yarn with 3.6 $\alpha$ e using slub yarn pattern $B$.

Figures 23(a), 23(b), and 23(c) show histograms for nominal values in the above sections and actual values in the lower sections for slub length, slub distance, and thickness, respectively. The distribution of actual slub length extends through a wider range with a higher mean, median, and mode values. The distribution of actual slub distance extends through approximately the same range but with lower mean, median, and mode values. The distribution of actual slub thickness extends through a wider range with slight higher mean, median, and mode values. As shown in Figure 24 the increase in slub length resulted in an increase of percentage of slub length in the yarn (SL\%) from 7.3 to $14.2 \%$ and the decrease of slub distance resulted in a decrease of percent of slub distance in the yarn (DL\%) from 92.7 to $85.8 \%$. The slight decrease in the total pattern length from 54.3 to $53.8 \mathrm{~m}$ leads to a very slight increase in number of slubs per meter from 1.822 to 1.84 . Table 2 summarizes results for slub yarn samples numbers 3, 4, and 5 in which the average difference between actual and nominal values in the three recorded signals were determined for the parameters STm, SDm, STm, and TL in each tested sample.

The increase of slub length may be due to the time lag between the electronic signals of speed change and the mechanical response caused by inertia of rotating masses. This time lag could be different in the two cases of accelerating 

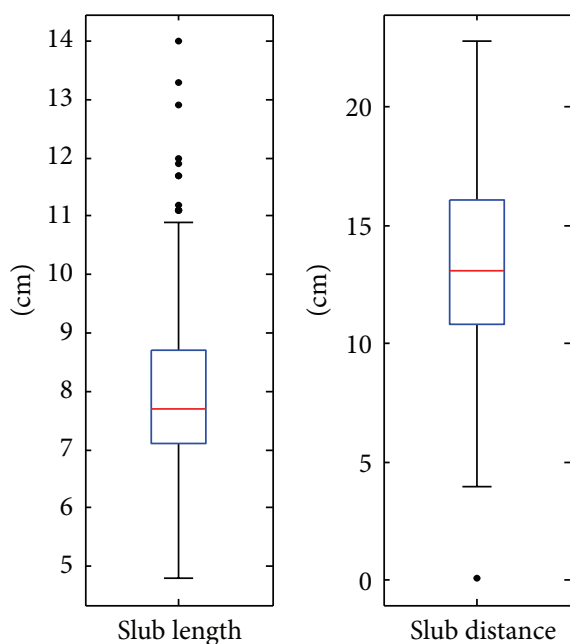

(a)

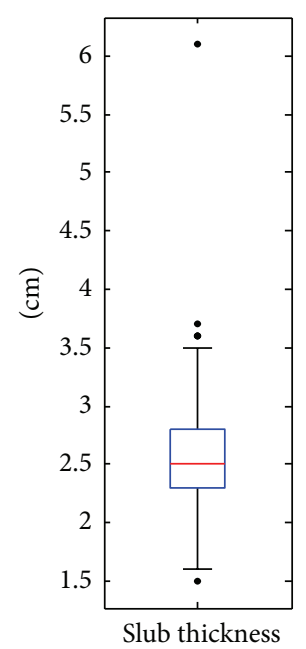

Slub yarn: $40 \mathrm{Ne}$, twist factor: 4.2 Program: A

Total length of tested yarn $(\mathrm{m})=244.18$

Number of slubs $=1138$

\begin{tabular}{|c|c|c|c|}
\hline Slub length: & & & \\
\hline - Long & 12 & - Low & 0 \\
\hline - Very long & g 1 & - Very low & 0 \\
\hline Slub distance: & & & \\
\hline - Long & 0 & - Low & 1 \\
\hline - Very long & g 0 & - Very low & 0 \\
\hline
\end{tabular}

Slub thickness:

- High 6 - Low 1

- Very high 2 - Very low 0

(b)

Figure 20: (a) Box plots for measured slub geometrical parameters. (b) Report of the number of detected outliers in slub yarn sample number 2 .

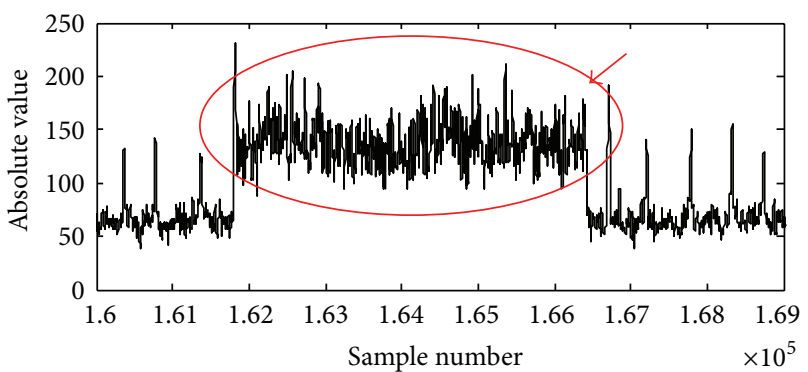

(a)

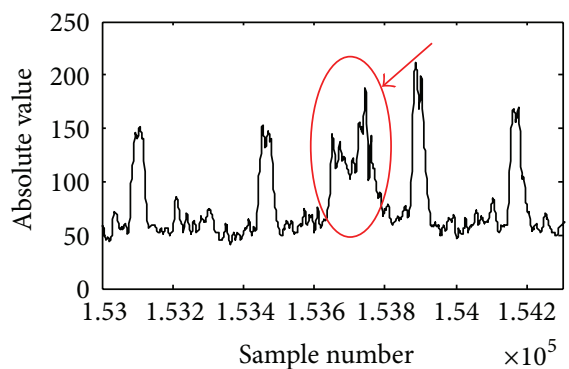

(b)

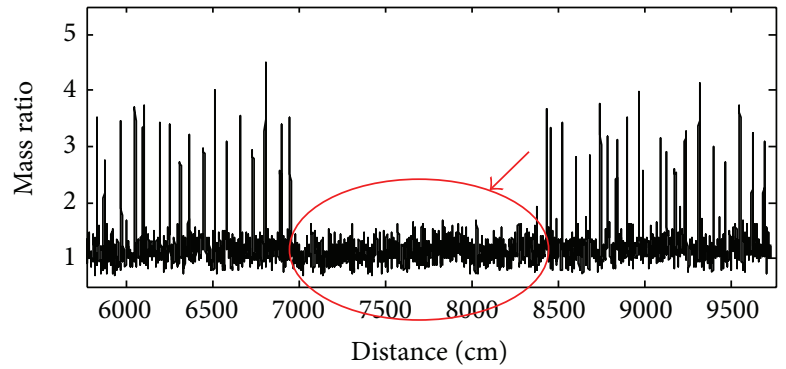

(c)

Figure 21: Examples of detected slubs with extreme characteristic.

and decelerating, that is, the time needed to decelerate a rotating roller from higher to lower speed is more than the time needed to accelerate it from lower to higher speed. As the decelerating signal is to end the slub part and in the same time to start the slub distance part, thus if the slub part extends this will decrease the length of the slub distance. Results in Table 2 show that the difference between actual and nominal mean slub length increased from 2.2 to $2.6 \mathrm{~cm}$ when the count increased from $24 \mathrm{Ne}$ to $36 \mathrm{Ne}$ in slub yarn samples produced using pattern A. Also, the difference between actual and nominal slub length increased from 2.6 to $3.2 \mathrm{~cm}$ in slub yarn samples of $36 \mathrm{Ne}(3.6 \alpha \mathrm{e})$ when the pattern changed from $A$ to $B$ which may be interpreted by the increase of nominal slub thickness from 2.55 in pattern A to 3.49 in pattern B, that is, the higher the speed the more time required to decelerate the roller to its original speed thus slub will extends more if slub thickness increased. Assessing the prevailing difference between actual and nominal values under different processing parameters needs more experimental study. 


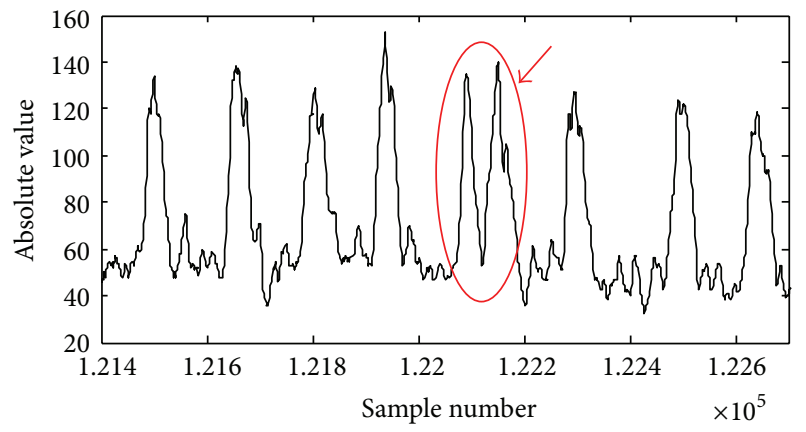

(a) Low slub distance

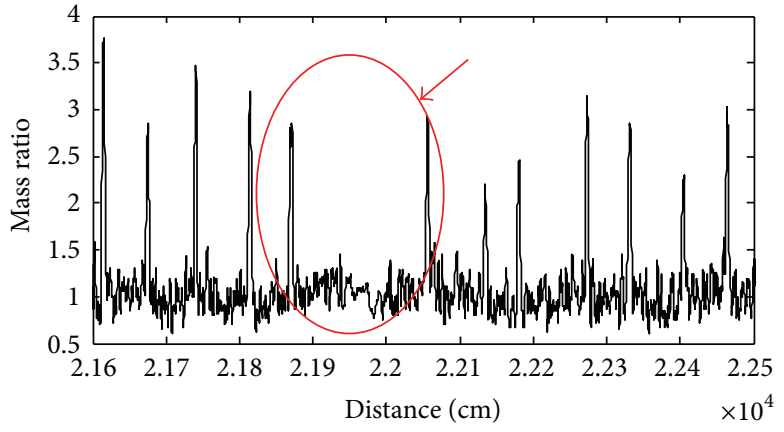

(b) Long slub distance due to missed slub over a short length

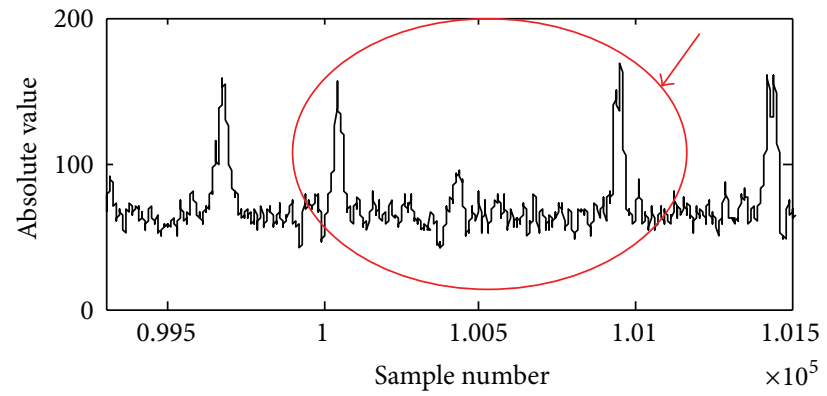

(c) Long slub distance due to very low slub thickness

FIgURE 22: Examples of detected low and long slub distance.

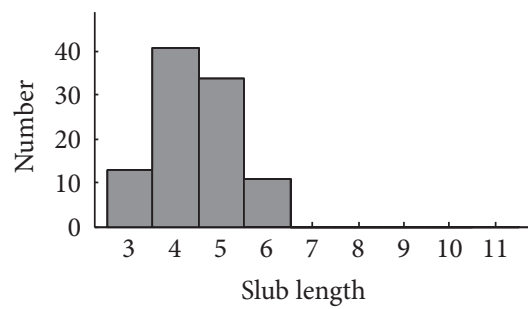

(A) Nominal: mean $=4.43$, std. $=0.86$, median $=4.00$, approx. mode $=4.00$

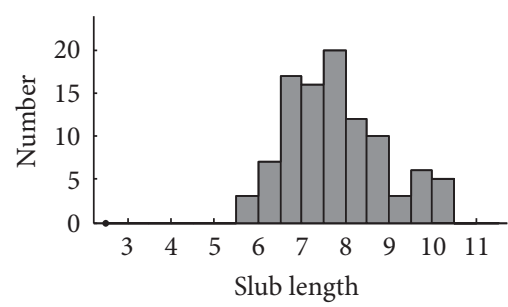

(B) Measured: mean $=7.71$, std. $=1.10$, median $=7.60$, approx. mode $=7.75$

(a)

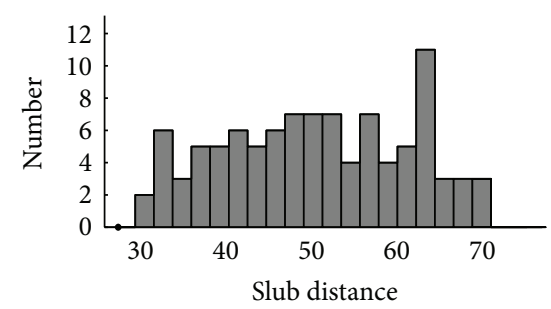

(A) Nominal: mean $=50.45$, std. $=10.70$, median $=51.00$, approx. mode $=62.99$

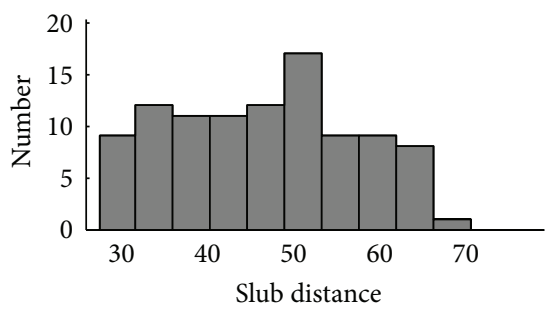

(B) Measured: mean $=46.61$, std. $=10.55$, median $=46.90$, approx. mode $=51.20$

(b)

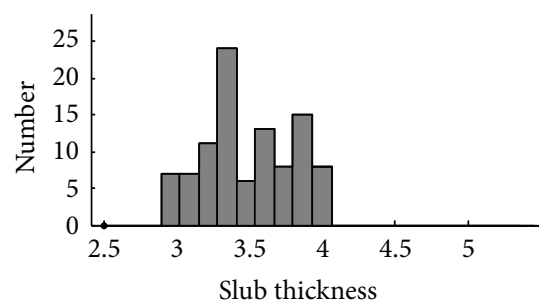

(A) Nominal: mean $=3.49$, std. $=0.30$, median $=3.50$, approx. mode $=3.34$

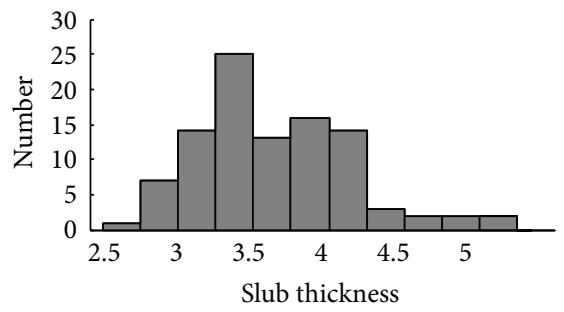

(B) Measured: mean $=3.66$, std. $=0.53$, median $=3.60$, approx. mode $=3.41$

(c)

FIGURE 23: Histogram comparison between actual and nominal slub geometrical parameters.

\section{Conclusion}

(i) A reliable system for evaluating different slub yarn characteristics based on the electrical condenser of the Uster evenness tester as a measuring sensor has been developed. The electrical output signal was fed into a digital storage oscilloscope and then analyzed using a proposed analysis method. Results from the proposed analysis method showed a very good correlation with the traditional manual measuring method. 


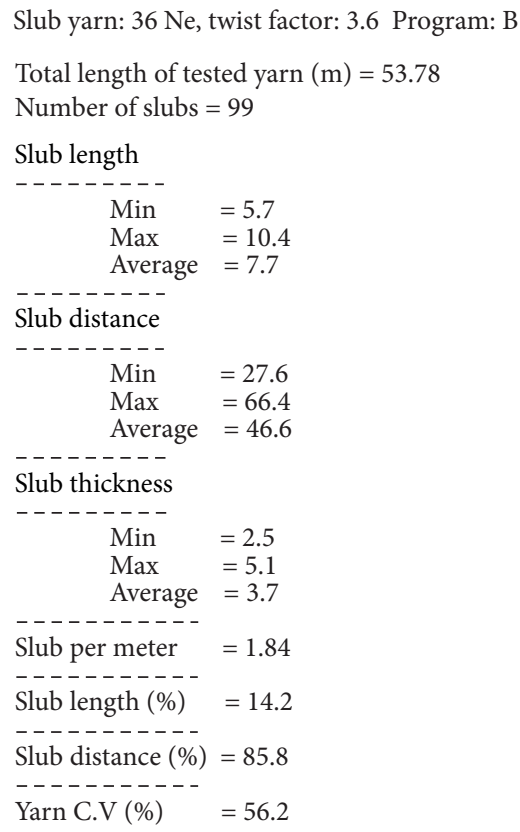

FIGURE 24: Final report for all the measured slub yarn characteristics in sample number 3.

(ii) By using a computer-designed program for signal analysis, the system is capable of measuring slub length, slub distance, slub thickness, number of slub per meter, percentage of slub length, percentage of base yarn length, and CV\% of tested slub yarn and base yarn. Final results from the system are graphical plots and a final report of all the measured characteristics.

(iii) Using box plot statistical method the system also makes it possible to detect slubs with outlier parameters which are considered slub yarn defects as very long slub length, very long slub distance, and very high slub thickness. A final report for the number of detected outliers was obtained which could be an effective industrial tool for evaluation of both yarn quality and machine performance. It is recommended also to evaluate the number of defects per constant unit length, for example, 1000 meter.

(iv) Actual slub geometrical parameters were compared by nominal values using histograms to assess their deviation. As the geometrical parameters of slub yarn determine the final appearance of the produced fabric, therefore the prevailing difference between actual and nominal values needs more experimental study to decide the causes and effect.

\section{Conflict of Interests}

The authors declare that there is no conflict of interests regarding the publication of this paper.

\section{References}

[1] R. H. Gong and R. M. Wright, Fancy Yarns: Their Manufacture and Application, Woodhead, Cambridge, UK, 2002.

[2] J. Sudhakar, Characterization methods and physical properties of Novelty yarn [M.S. thesis], Textile Management and Technology, College of Textiles, Raleigh, NC, USA, 2005.

[3] R. Pan, W. Gao, J. Liu, and H. Wang, "Recognition the parameters of slub-yarn based on image analysis," Journal of Engineered Fibers and Fabrics, vol. 6, no. 1, pp. 25-30, 2011.

[4] J. Liu, Z. Li, Y. Lu, and H. Jiang, "Visualization and determination of the geometrical parameters of slub yarn," Fibres \& Textiles in Eastern Europe, vol. 18, no. 1 (78), pp. 31-35, 2010.

[5] J. Liu and Y. Lu, "Recognition method for the slub yarn's apparent parameters based on FFT," in Proceedings of the 86th Textile Institute World Conference, pp. 2567-2573, 2008.

[6] J. Liu, Z. Xie, W. Gao, and H. Jiang, "Automatic determination of slub yarn geometrical parameters based on an amended similarity-based clustering method," Textile Research Journal, vol. 80, no. 11, pp. 1075-1082, 2010.

[7] E. Sandra, "Uster tester 5-S8000 application report measurement of slub yarns partl-basics," 2007, http://www.uster .com/en/service/downloadcenter/U_T5_S800_Measurement_ of_slub_yarns_Basic.pdf.

[8] A. G. Z. Uster, "Application Handbook for evenness testers of the type Uster evenness Tester (GGP B/C)," Uster Tester I B/C and Uster Tester II B/C, CH-8610 Uster/Switzerland.

[9] W. Steven Smith, The Scientist and Engineer's Guide to Digital Signal Processing, California Technical Publishing, San Diego, Calif, USA, 2nd edition.

[10] H. Breny, "The calculation of the variance length curve from the length distribution of fibers," The Journal of Textile Institute, vol. 44, no. 1, pp. 1-9, 1953.

[11] D. L. Massart, J. Smeyers-Verbeke, X. Capron, and K. Schlesier, "Visual presentation of data by means of box plots," LC-GC Europe, vol. 18, no. 4, pp. 215-218, 2005.

[12] CAIPO, Biella, Italy, http://www.caipo.com/. 

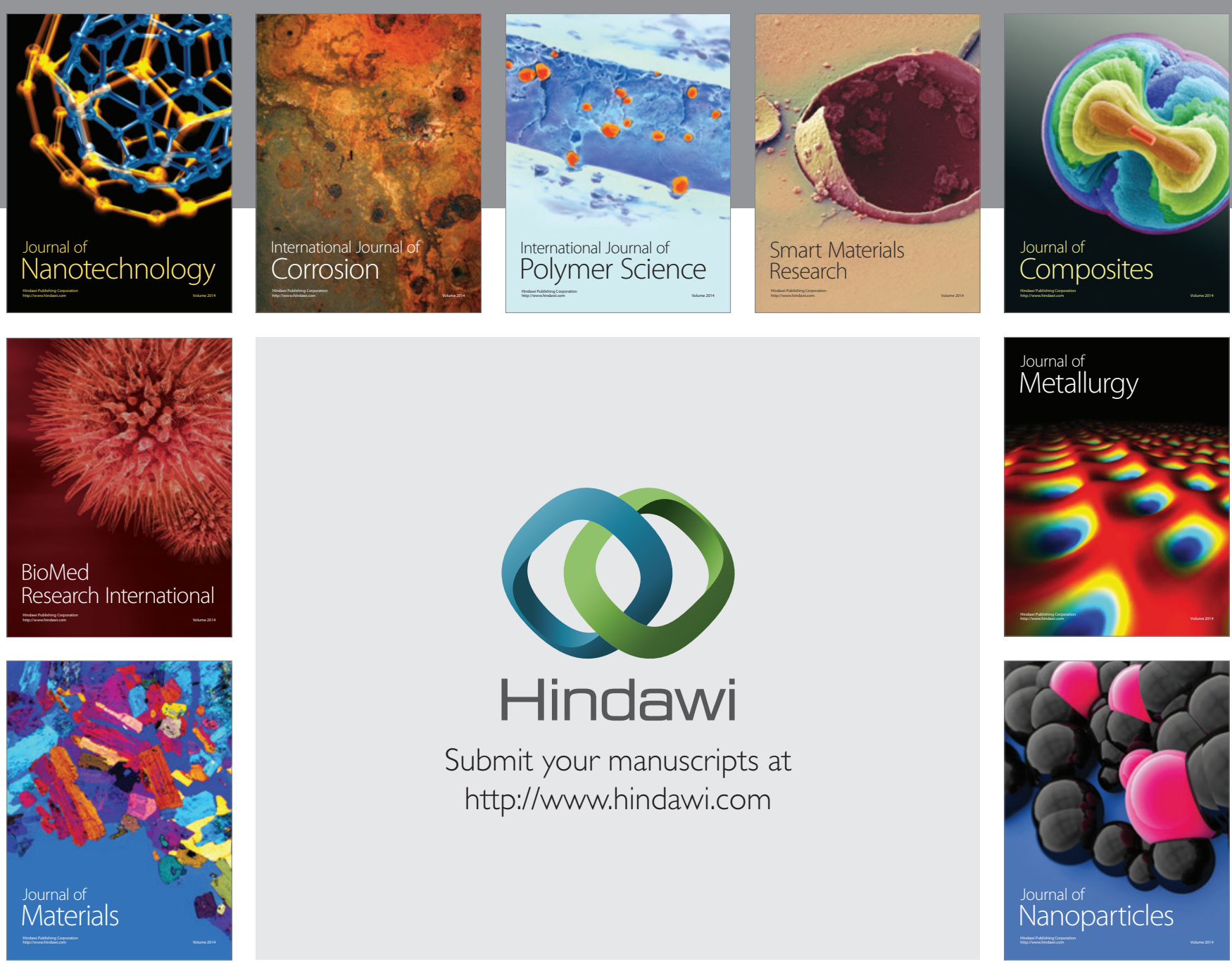

Submit your manuscripts at http://www.hindawi.com
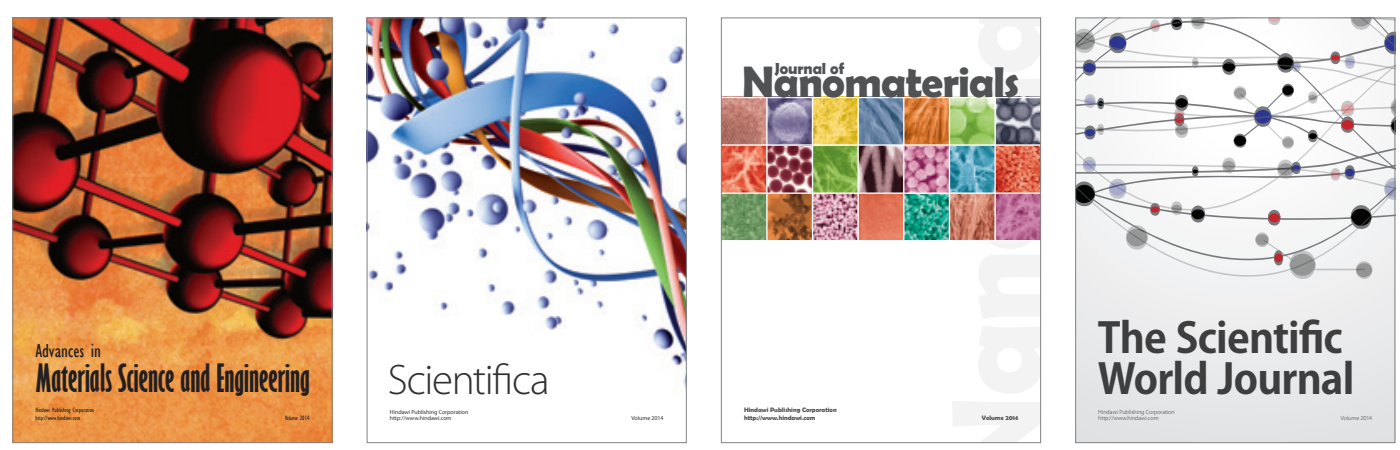

\section{The Scientific World Journal}
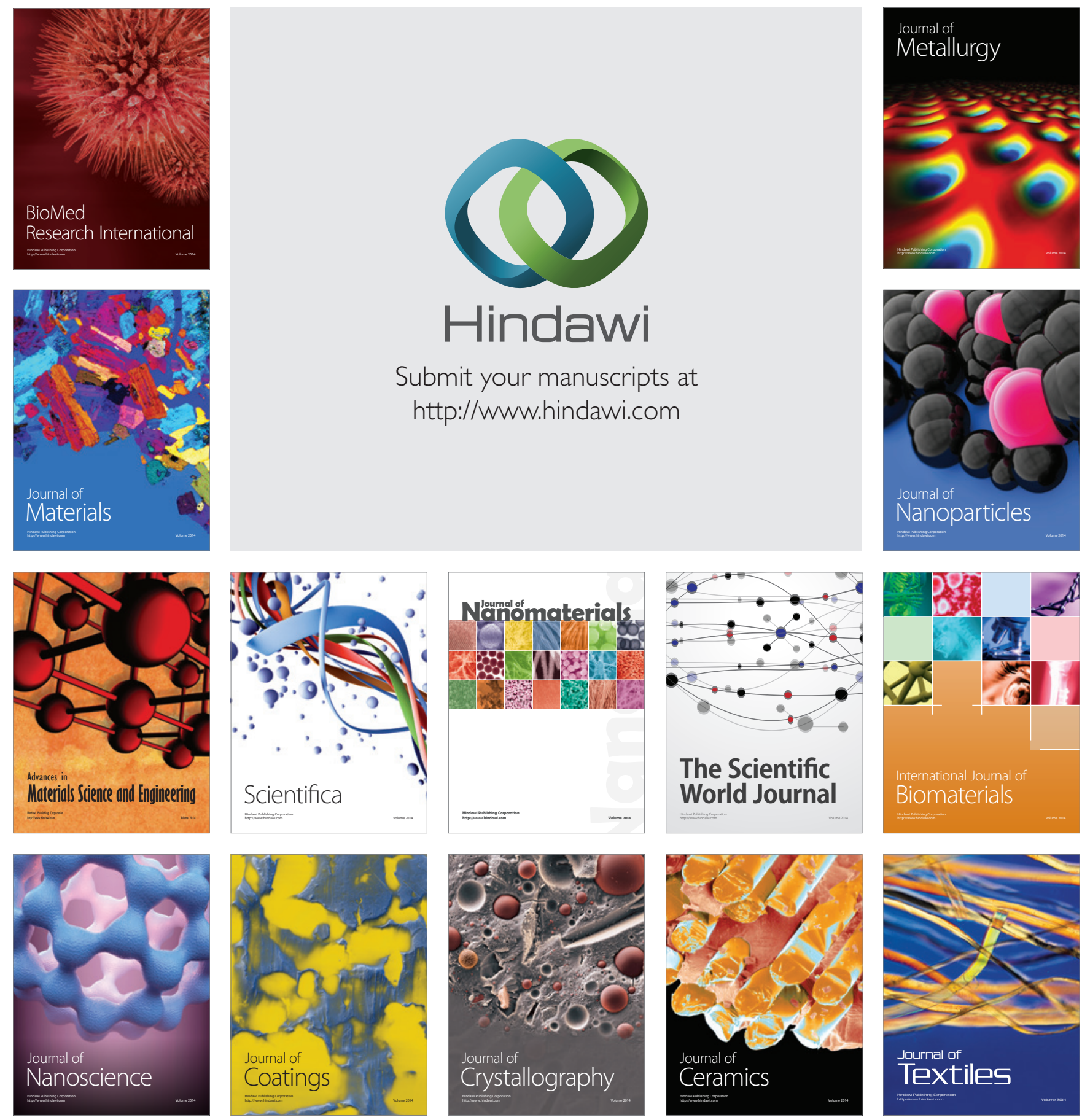